\title{
Changes in intercellular coupling between pig oocytes and cumulus cells during maturation in vivo and in vitro
}

\author{
J. Motlik, J. Fulka and J.-E. Fléchon* \\ Czechoslovak Academy of Sciences, Institute of Animal Physiology and Genetics, Department of \\ Genetics, 27721 Liběchov, Czechoslovakia, and ${ }^{*}$ I.N.R.A., Station Centrale de Physiologie Animale, \\ 78350 Jouy-en-Josas, France
}

\begin{abstract}
Summary. Cumulus expansion and cumulus cell-oocyte coupling during in-vivo and in-vitro maturation of pig oocytes were studied by measuring $\left[{ }^{3} \mathrm{H}\right]$ uridine uptake. In vivo, cumulus expansion started before germinal vesicle breakdown (GVBD) (16 h versus $20 \mathrm{~h}$ after hCG) but no significant change occurred in the coupling index until $32 \mathrm{~h}$ after hCG. Intercellular coupling was decreasing at $32 \mathrm{~h}$ after hCG in oocytes at anaphase I and telophase I. Complete uncoupling was closely correlated with corona radiata expansion. In vitro, partial uncoupling was observed in oocyte-cumulus cell complexes from prepubertal and PMSG-stimulated gilts cultured for 16 and $32 \mathrm{~h}$, respectively. The addition of FSH caused cumulus expansion, and the functional coupling between the cumulus cells and the oocyte was maintained up to at least $16 \mathrm{~h}$ of culture in complexes from prepubertal gilts.

We conclude that, under our conditions, neither hormone-free nor FSHsupplemented medium ensured the same $\left[{ }^{3} \mathrm{H}\right]$ uridine uptake and uncoupling kinetics as during in-vivo maturation.
\end{abstract}

\section{Introduction}

The endogenous LH peak initiates in Graafian follicles specific alterations in follicular steroidogenesis, changes in the cumulus cell-oocyte complex, and resumption of meiosis. The morphological transformation of the cumulus oophorus, referred to as 'expansion' or 'mucification' (Dekel \& Kraicer, 1978; Eppig, 1979), may lead to a decreased integrity of junctional complexes between the cumulus cells and between the corona cell processes and the oolema (Gilula, Epstein \& Beers, 1978; Szöllözi \& Gérard, 1983). The reduction of gap junctions may result in the decrease of ionic coupling and metabolic co-operation between cumulus cells and the oocyte (Gilula et al., 1978; Heller \& Schultz, 1980). In the pig, it is not known whether mucification (Hillensjö \& Channing, 1980 ) corresponds to such a decrease in intercellular communications.

It has been shown that $\left[{ }^{3} \mathrm{H}\right]$ uridine and $\left[{ }^{3} \mathrm{H}\right]$ choline gain access to oocytes mainly via the cumulus cell processes connecting these cells with the immature oocyte (Moor, Smith \& Dawson, 1980; Heller \& Schultz, 1980). These precursors have been used as markers to determine the decrease in intercellular coupling during the maturation of mouse (Eppig, 1982; Eppig \& WardBailey, 1982; Salustri \& Siracusa, 1983) and sheep (Moor, Osborn, Cran \& Walters, 1981) oocytes. Changes in intercellular coupling observed during in-vitro culture of intact sheep follicles in a medium with gonadotrophins were comparable with those occurring in vivo (Moor et al., 1980). However, uncoupling in mouse isolated cumuli oophori cultured in hormone-free media was different from that obtained in vivo or in FSH-supplemented medium (Salustri \& Siracusa, 1983).

The present experiments were designed to correlate the time sequence of pig oocyte maturation, cumulus expansion and cumulus cell-oocyte uncoupling in vivo and in vitro. 


\section{Materials and Methods}

The cumulus cell-oocyte relationship in vivo was examined in miniature pig gilts (crosses of the Minnesota and Göttingen strains) stimulated with 500 i.u. PMSG (Antex; Leo, Copenhagen, Denmark) on Day 16 of the cycle and 72 h later with 500 i.u. hCG (Praedyn, Spofa). Cumulusoocyte complexes were isolated from ovaries excised by bilateral ovariectomy performed at 0,16 , 24,32 or $40 \mathrm{~h}$ after the hCG injection. The ovaries were immediately put in prewarmed phosphatebuffered saline (PBS, pH 7.4), and the follicular wall of the preovulatory follicles was perforated with a fine stainless-steel needle under a dissecting microscope. The aspect of the connection between the parietal granulosa and the cumulus was noted. The isolated cumulus-oocyte complexes at each time were divided into two groups and the cumulus cells of one group were removed with fine pipettes after hyaluronidase treatment; the cumulus-enclosed and denuded oocytes of the two groups were incubated in the labelled medium (see below).

The cumulus-oocyte complexes for in-vitro maturation were isolated from the ovaries of slaughtered prepubertal gilts of the Large-White breed (Motlik, 1972) or from the ovaries of cyclic miniature pig gilts slaughtered $72 \mathrm{~h}$ after PMSG injection as above. The cumulus-oocyte complexes of both groups were cultured in vitro for $1,16,24,32$ or $40 \mathrm{~h}$ in $0 \cdot 1 \mathrm{ml}$ medium under paraffin oil at $38^{\circ} \mathrm{C}$ in air containing $5 \% \mathrm{CO}_{2}$. The culture medium was TC 199 (USOL, Prague) supplemented with sodium pyruvate $(0.04 \mathrm{mg} / \mathrm{ml})$ and freeze-dried calf serum growth proteins (USOL, Prague) at a concentration of $30 \mathrm{mg} / \mathrm{ml}$ (Motlik \& Fulka, 1974). In parallel experiments, pig FSH (Calbiochem, La Jolla, CA, USA) was added to the culture medium at a concentration of $2.5 \mathrm{mg} / \mathrm{ml}$. At the end of the culture period, one-half of the oocytes in each group were entirely deprived of cumulus cells. All oocytes and cumulus cell-oocyte complexes were incubated for $1 \mathrm{~h}$ in the culture medium enriched with $\left[5-{ }^{3} \mathrm{H}\right]$ uridine (UVVVR, Prague; sp. act. $20 \cdot 6 \mathrm{Ci} / \mathrm{mol}$ ) at a concentration of $100 \mu \mathrm{Ci} / \mathrm{ml}$. From each experimental group, 5 or 10 sets of 10 denuded oocytes were washed 5 times in PBS and transferred in a minimal volume to scintillation counting vials containing $40 \mu \mathrm{l} \mathrm{NCS} \mathrm{tissue} \mathrm{solubilizer} \mathrm{(Amersham).} \mathrm{Then} \mathrm{the} \mathrm{oocytes} \mathrm{were} \mathrm{solubilized,} 6 \mathrm{ml}$ of scintillation liquid SLT 31 (Spolana, Neratovice) were added, and the samples were measured by scintillation spectroscopy using Isocap II (Nuclear, Chicago, IL, U.S.A.). The intercellular coupling index was calculated by the formula of Heller, Cahill \& Schultz (1981), i.e. (A - B)/B, where $A$ is the number of c.p.m. per cumulus-enclosed oocyte and $B$ is the number of c.p.m. per cumulus-free oocyte.

For each combination of materials and treatments, the comparison of the calculated coupling indices obtained for the different experimental times was carried out, after log transformation, by two-way analysis of variance and Duncan's new multiple test range.

The nuclear maturation of about 10 oocytes in each of the in-vivo and in-vitro experiments was examined by phase-contrast microscopy in whole mount preparations fixed in acetic alcohol (1:3, v/v) and stained with $1 \%$ orcein.

\section{Results}

\section{Cumulus expansion and cumulus cell-oocyte coupling during in-vitro maturation}

Preovulatory changes in the aspect of connection between the parietal granulosa cells and the cumulus cell-oocyte complex in pigs are outlined in Fig. 1. In follicles isolated $72 \mathrm{~h}$ after PMSG injection (hCG: $0 \mathrm{~h}$ ), the dense cumulus cell mass was characterized by a high coupling index $(1 \cdot 8)$ with the oocyte (Fig. 2). The intercellular deposits of the mucous matrix amongst the cells forming the connection of the cumulus oophorus with the parietal granulosa were first seen $16 \mathrm{~h}$ after hCG. Absolute values of $\left[{ }^{3} \mathrm{H}\right]$ uridine uptake and of the coupling index were not significantly changed at this stage. By $24 \mathrm{~h}$ after hCG the cumulus was well expanded. The inner cumulus cell layers (corona 
(a) $\mathrm{Oh}$

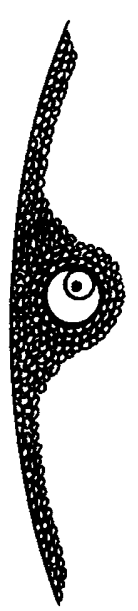

(b) $16 \mathrm{~h}$

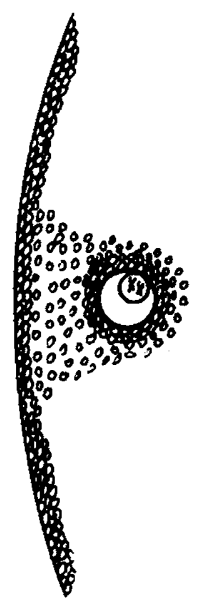

(c) $24 \mathrm{~h}$

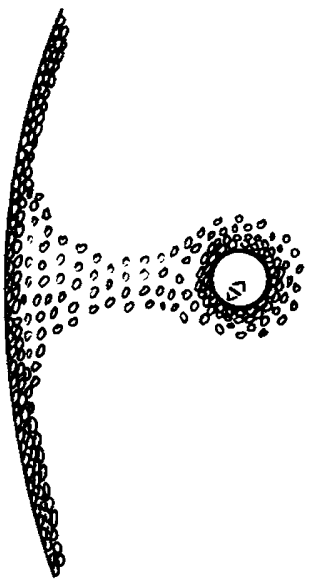

(d) $32 \mathrm{~h}$

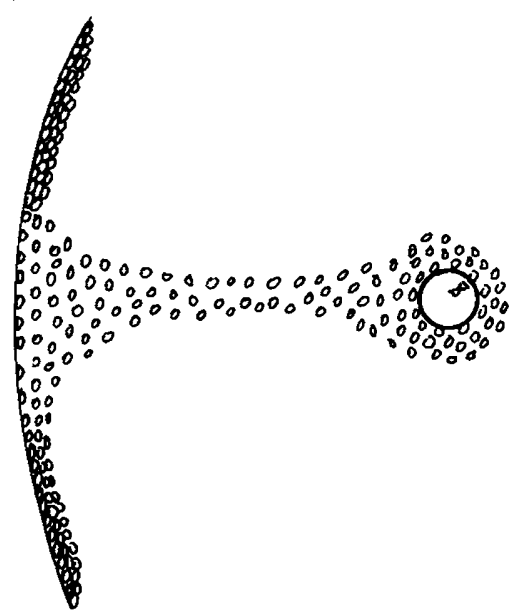

Fig. 1. Preovulatory changes in the granulosa cell-oocyte complex in pigs. Oocytes in preovulatory follicles isolated $72 \mathrm{~h}$ after PMSG are surrounded by a dense cumulus cell mass and the cumulus cells are connected with the parietal granulosa cells (a). The initial symptoms of cumulus expansion are evident $16 \mathrm{~h}$ after $\mathrm{hCG}$. The first signs of matrix deposition are observed mainly among cells forming the connection between the cumulus and the parietal granulosa (b). At $24 \mathrm{~h}$ after hCG the cumulus is very expanded. Its firm, elastic stalk makes contact with the parietal granulosa by a foot of about $5 \mathrm{~mm}^{2}$. The inner cumulus cell layers constituting the corona radiata are still intimately connected with the oocyte (c). At $32 \mathrm{~h}$ after hCG, the elastic junction between the expanded cumulus and the parietal granulosa is looser; however the cumulus-oocyte complex could not be removed from the follicle by aspiration. The layer of corona radiata cells is less compact (d).

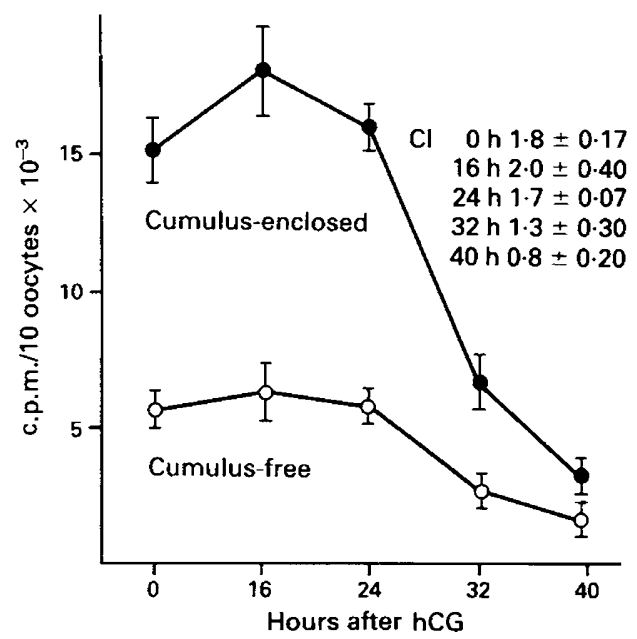

Fig. 2. Uptake of $\left[{ }^{3} \mathrm{H}\right]$ uridine by cumulus-enclosed oocytes and cumulus-free oocytes isolated from preovulatory follicles $0,16,32$ and $40 \mathrm{~h}$ after hCG. Five sets of 10 oocytes and of 10 cumulus cell-oocyte complexes were incubated in the radioactive medium for $1 \mathrm{~h}$ and uptake in the oocytes was measured by scintillation spectroscopy. Each point represents the mean \pm s.e.m. of 5 experiments. The intercellular coupling index (CI) was calculated for each group. Only the CI at $40 \mathrm{~h}$ was significantly different from that of $0-24 \mathrm{~h}(P<0.025)$; the CI of $32 \mathrm{~h}$ did not differ significantly from that at other times. 
radiata) were still intimately connected with the oocytes as shown by the high value of the coupling index $(1 \cdot 7)$. When these oocytes were treated with hyaluronidase, only the expanded cumulus was dispersed and the corona radiata remained in contact with the oocytes. $\left[{ }^{3} \mathrm{H}\right]$ Uridine uptake in oocytes with a corona radiata was comparable with that obtained for cumulus-enclosed oocytes at this stage (data not shown). It was concluded that the corona radiata cells ensured the effective

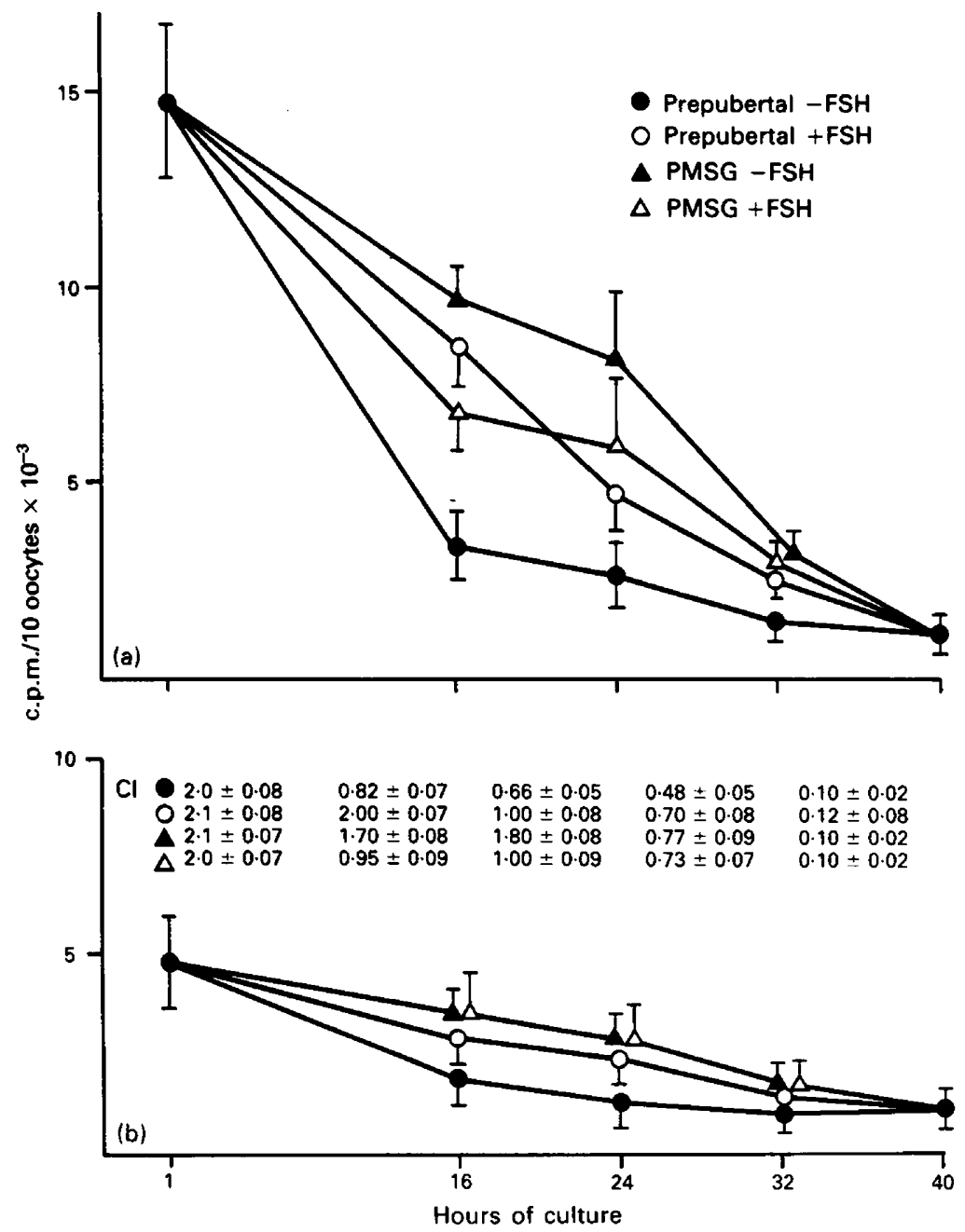

Fig. 3. Uptake of $\left[{ }^{3} \mathrm{H}\right]$ uridine by (a) cumulus-enclosed and (b) cumulus-free oocytes isolated from prepubertal and PMSG-treated (PMSG) gilts. Cumulus-oocyte complexes were cultured for $1,16,24,32$ and $40 \mathrm{~h}$, and then 10 sets of 10 oocytes and of 10 cumulus cell-oocyte complexes were incubated in the radioactive medium for $1 \mathrm{~h}$. The uptake of precursor in the oocytes was measured by scintillation spectroscopy. Each point represents the mean \pm s.e.m. of 10 experiments. The intercellular coupling index (CI) was calculated for each group. For complexes from prepubertal gilts, the CI values were significantly different between $1 \mathrm{~h}$ and $16-32 \mathrm{~h}$ and between the latter and $40 \mathrm{~h}(P<0 \cdot 01)$ without FSH. With FSH the values were significantly different between 16 and $24 \mathrm{~h}$, and between 32 and $40 \mathrm{~h}(P<0.01)$. For complexes from PMSG-treated gilts, CI values were significantly different between 24 and $32 \mathrm{~h}$ and between 32 and $40 \mathrm{~h}$ without FSH. With FSH, the values were significantly different between 1 and 16-32 h and between 32 and $40 \mathrm{~h}$. 
contact of the oocyte with the follicular environment until $24 \mathrm{~h}$ after hCG. A drop in $\left[{ }^{3} \mathrm{H}\right]$ uridine uptake and in the coupling index was recorded $32 \mathrm{~h}$ after hCG. At this stage, the process of cumulus expansion was also evident in the corona radiata cells. However, the expanded cumulus was still connected with the parietal granulosa (see Fig. 1). At $40 \mathrm{~h}$ after hCG, the cumulus cell-oocyte complex escaped with the follicular fluid when the follicular cavity was opened. The coupling index significantly decreased to less than 1 .

A comparison of $\left[{ }^{3} \mathrm{H}\right]$ uridine uptake with the timing of nuclear maturation indicated that the oocyte and the follicular cells were intimately coupled at the germinal vesicle stage $(0$ and $16 \mathrm{~h}$ after hCG) and at metaphase I, that is, at the time the most condensed bivalents became visible, as does the spindle when favourably orientated ( $24 \mathrm{~h}$ after $\mathrm{hCG}$ ). Cumulus expansion started before germinal vesicle breakdown (GVBD), but the coupling index did not change until $24 \mathrm{~h}$ after hCG injection. Intercellular coupling between the oocyte and the cumulus cells was decreasing at $32 \mathrm{~h}$ after hCG when anaphase I or telophase I prevailed. Decoupling was correlated with the expansion of the corona radiata cells. Very little $\left[{ }^{3} \mathrm{H}\right]$ uridine was taken up by the oocytes at metaphase II $(40 \mathrm{~h}$ after hCG).

\section{Cumulus expansion and cumulus cell-oocyte coupling during in-vitro maturation}

The intercellular coupling index in prepubertal or PMSG-stimulated gilts was studied in oocytecumulus cell complexes isolated after culture for 1, 16, 24, 32 or $40 \mathrm{~h}$ (Fig. 3). In both groups, the freshly-isolated oocytes incubated only for $1 \mathrm{~h}$ in hormone-free (control) or FSH-supplemented medium had a high coupling index $(2 \cdot 0-2 \cdot 2)$. In prepubertal gilt oocytes cultured in the control medium, the uptake of the precursor as well as the coupling index decreased substantially $(0 \cdot 82)$ after $16 \mathrm{~h}$ of culture. The index value dropped again at $40 \mathrm{~h}$ of culture. Compact cumuli did not expand in the control medium, but cumulus cells attached to the surface of the culture dish and formed a monolayer. These data show that in the control medium prepubertal gilt oocyte-cumulus complexes had changed to a lower coupling value even after only $16 \mathrm{~h}$ of culture.

The presence of FSH in the medium changed the pattern of intercellular coupling and cumulus behaviour in vitro. At 16 and $24 \mathrm{~h}$ of culture, cumulus expansion was induced, although the cells of the corona radiata were still closely attached to the oocytes. Although the absolute values of $\left[{ }^{3} \mathrm{H}\right]-$ uridine uptake dropped substantially, the coupling index was 2.0 at $16 \mathrm{~h}$ and 1.0 at $24 \mathrm{~h}$. At 32 and $40 \mathrm{~h}$ of culture, the cumulus was completely expanded and partly detached from the oocyte and did not form a monolayer on the culture dish as in the control medium. The coupling index declined from 0.7 at $32 \mathrm{~h}$ to 0.1 at $40 \mathrm{~h}$.

In the second group of experiments with oocyte-cumulus cell complexes isolated $72 \mathrm{~h}$ after PMSG injection, and after culture in the presence of FSH, the results were similar to those obtained with FSH-treated material from prepubertal gilts (Fig. 3); the cumulus was expanded but the coupling index decreased significantly $(<1)$, even by $16 \mathrm{~h}$. In contrast, the $\left[{ }^{3} \mathrm{H}\right]$ uridine uptake and coupling index remained high $(1.7$ and 1.8$)$ after 16 and $24 \mathrm{~h}$ of culture in the control medium where no expansion occurred. It is evident that, in the control medium, the pattern of oocyte-cumulus cell complex uncoupling differed substantially between prepubertal and PMSG-stimulated gilts.

\section{Discussion}

About $12 \mathrm{~h}$ after hCG treatment, when rodents ovulate, pig oocytes still show a germinal vesicle with only the first symptoms of chromatin condensation (Motlik \& Fulka, 1976). By $24 \mathrm{~h}$ after hCG, when sheep and cattle oocytes have already completed maturation, pig oocytes reach prometaphase or metaphase I (Hunter \& Polge, 1966). This means that the nucleus of pig oocytes takes 3 times longer to mature than that of rodents and twice as long as those of sheep or cattle. Similarly, while intercellular modifications leading to cumulus expansion appear in rats and mice at 4.5 and 
$6 \mathrm{~h}$, respectively, after hCG stimulation, the first intercellular deposits of a mucous matrix were observed in pigs $16 \mathrm{~h}$ after hCG. It is clear that GVBD precedes cumulus expansion in rodents (Dekel, Hillensjo \& Kraicer 1979; Eppig, 1982). At the time of GVBD in pigs, 20-24 h after hCG (Motlik \& Fulka, 1976), the outer layers of the cumulus cells were very expanded. Intercellular deposits of mucous matrix were first seen in the connection between the parietal granulosa and the cumulus cells. Thus, the contact of the cumulus-oocyte complex with the follicular wall was distended before the contact of the oocyte with the corona radiata cells. In fact, cumulus expansion at metaphase I was limited to the outer layers of the cumulus cells, while the layers adjacent to the oocyte were still tightly packed as in other species (Dekel, Kraicer, Phillips, Sanchez \& Segal, 1978; Eppig, 1982). In sheep follicles cultured for $12 \mathrm{~h}$ with gonadotrophins, meiotic maturation progresses to prometaphase or metaphase I while intercellular coupling is only slightly reduced (Moor et al., 1980). The index of oocyte-cumulus cell coupling in mouse oocytes isolated $6 \mathrm{~h}$ after hCG (Eppig, 1982) and in pig oocytes isolated $24 \mathrm{~h}$ after hCG (present results) was not lower than that observed before hCG stimulation. These results clearly demonstrate that the innermost cumulus cells ensure the intimate association of the oocyte with the follicular environment, at least up to metaphase I. The oocyte and corona radiata remain tightly coupled in pig and other species, even though the oocyte has already resumed meiosis (Eppig, 1982). After hCG stimulation, the process of cumulus expansion also becomes evident in the corona radiata cells. The mouse cumulus completely expands $9 \mathrm{~h}$ after hCG, when the cumulus cell-oocyte coupling index declines markedly (Eppig, 1982). The onset of decrease in $\left[{ }^{3} \mathrm{H}\right]$ uridine uptake by pig oocytes $32 \mathrm{~h}$ after hCG was also correlated with full cumulus expansion in the present experiment.

The persistence of coupling between the oocytes and the follicular cells in vivo until metaphase I raises the question of its role in oocyte ability to develop after fertilization. In several species only oocytes isolated from preovulatory follicles with an expanded cumulus, and which have progressed to metaphase I, are able to attain full development (Thibault, 1972; Motlik \& Fulka, 1974; Niwa, Miyake, Iritani \& Nishikawa, 1976). Again, only oocytes cultured in follicles (Moor \& Trounson, 1977), co-cultured with granulosa cells (Motlik \& Fulka, 1981; Staigmiller \& Moor, 1984), or cultured within the cumulus in medium with LH (Shalgi, Dekel \& Kraicer, 1979) show good developmental competence after fertilization. This means that the intimate contact between the oocyte and its follicular environment up to metaphase $I$ is a prerequisite for the development of normal embryos and viable young. Only Schroeder \& Eppig (1984) reported that normal developmental competence was obtained during the spontaneous maturation of both cumulus-enclosed and cumulus-free mouse oocytes cultured in the presence of fetal bovine serum or heat-inactivated mouse serum.

A comparison of the data obtained in our in-vitro experiments reveals that $\left[{ }^{3} \mathrm{H}\right]$ uridine uptake varies considerably according to the culture conditions. The most striking fact is the rapid drop of the coupling index in cumulus-enclosed oocytes from prepubertal gilts after $16 \mathrm{~h}$ of culture in a hormone-free medium. The functional coupling between the cumulus cells and the oocytes was observed to last up to $24 \mathrm{~h}$ in oocytes from the PMSG-treated gilts. FSH-supplemented medium consistently induced cumulus expansion; it delayed the onset of uncoupling in complexes from prepubertal gilts but hastened that of material from PMSG-treated gilts. Moreover, the level of $\left[{ }^{3} \mathrm{H}\right]$ uridine uptake was lower than for in-vivo matured material (Figs $2 \& 3$ ). Therefore, it can be concluded that, under our conditions, neither hormone-free nor FSH-supplemented medium ensured the same uncoupling between the oocyte and the cumulus cells as during in-vivo maturation. Further investigation of metabolic co-operation in oocyte-cumulus cell complexes may help to develop the culture conditions needed for the complete normal maturation in vitro.

We thank Mrs J. Novotna for technical assistance, Miss A. Solari for the statistical analyses and Mrs A. Daifuku for editing the text. 


\section{References}

Dekel, N. \& Kraicer, P.F. (1978) Induction in vitro of mucification of rat cumulus oophorus by gonadotrophins and adenosine $3^{\prime}, 5^{\prime}$-monophosphate. Endocrinology 102, 1797-1802.

Dekel, N., Kraicer, P.F., Phillips, D.M., Sanchez, R.S. \& Segal, S.J. (1978) Cellular association in the rat oocyte-cumulus cell complex: morphology and ovulatory changes. Gamete Res. 1, 47-57.

Dekel, N., Hillensjö, T. \& Kraicer, P.F. (1979) Maturational effect of gonadotrophins on the cumulusoocyte complex in the rat. Biol. Reprod. 20, 191-197.

Eppig, J.J. (1979) Gonadotropin stimulation of the expansion of cumulus oophori isolated from mice: general conditions for expansion in vitro. $J$. exp. Zool. 208, 11-120.

Eppig, J.J. (1982) The relationship between cumulusoocyte coupling, oocyte meiotic maturation, and cumulus expansion. Devl Biol. 89, 268-272.

Eppig, J.J. \& Ward-Bailey, P.F. (1982) The mechanism of cumulus cell-oocyte uncoupling; evidence for the participation of both cumulus cells and oocytes. Gamete Res. 6, 145-154.

Gilula, N.B., Epstein, M.L. \& Beers, W.N. (1978). Cellto-cell communication and ovulation: a study of the cumulus-oocyte complex. J. Cell Biol. 78, 58-75.

Heller, D.T. \& Schultz, R.M. (1980) Ribonucleoside metabolism by mouse oocytes: metabolic cooperativity between fully grown oocytes and cumulus cells. J. exp. Zool. 214, 355-364.

Heller, D.T., Cahill, D.M. \& Schultz, R.M. (1981) Biochemical studies of mammalian oogenesis: metabolic cooperativity between granulosa cells and growing mouse oocytes. Devl Biol. 84, 445-464.

Hillensjö, T. \& Channing, C.P. (1980) Gonadotropin stimulation of steroidogenesis and cellular dispersion in cultured porcine cumuli oophori. Gamete Res. $\mathbf{3}$, 233-240.

Hunter, R.H.F. \& Polge, C. (1966) Maturation of follicular oocytes in the pig after injection of human chorionic gonadotrophin. J. Reprod. Fert. 12, 525-531.

Moor, R.M. \& Trounson, A.O. (1977) Hormonal and follicular factors affecting maturation of sheep oocytes in vitro and their subsequent developmental capacity. J. Reprod. Fert. 49, 101-109.

Moor, R.M., Smith, M.W. \& Dawson, M.C. (1980) Measurement of intercellular coupling between oocytes and cumulus cells using intracellular markers. Expl Cell Res. 126, 15-29.
Moor, R.M., Osborn, J.C., Cran, D.G. \& Walters, D.E. (1981) Selective effect of gonadotrophins on cell coupling, nuclear maturation and protein synthesis in mammalian oocytes. J. Embryol. exp Morph. 61, 347-365.

Motlik, J. (1972) Cultivation of pig oocytes in vitro. Folia biol. (Praha) 18, 345-349.

Motlik, J. \& Fulka, J. (1974) Fertilization of pig follicular oocytes in vitro. J. Reprod. Fert. 36, 235-237.

Motlik, J. \& Fulka, J. (1976) Breakdown of the germinal vesicle in pig oocytes in vivo and in vitro. $J$. exp. Zool. 198, 155-162.

Motlik, J. \& Fulka, J. (1981) Fertilization of rabbit oocytes co-cultured with granulosa cells. J. Reprod. Fert. 63, 425-429.

Niwa, K., Miyake, M., Iritani, A. \& Nishikawa, Y. (1976) Fertilization of rat oocytes cultured in vitro from various stages of maturation. J. Reprod. Fert. 47, 105-106.

Salustri, A. \& Siracusa, G. (1983) Metabolic coupling, cumulus expansion and meiotic resumption in mouse cumuli oophori cultured in vitro in the presence of FSH or dcAMP, or stimulated in vivo by hCG. $J$. Reprod. Fert. 68, 335-341.

Schroeder, A.C. \& Eppig, J.J. (1984) The development capacity of mouse oocytes that matured spontaneously in vitro is normal. Devl Biol. 102, 493-497.

Shalgi, R., Dekel, N. \& Kraicer, P.F. (1979) The effect of LH on fertilizability and developmental capacity of rat oocytes matured in vitro. J. Reprod. Fert. 55, 429-435.

Stagmiller, R.B. \& Moor, R.M. (1984) Effect of follicle cells on the maturation and developmental competence of ovine oocytes matured outside the follicle. Gamete Res. 9, 221-229.

Szöllösi, D. \& Gerard, M. (1983) Cytoplasmic changes in the mammalian oocytes during the preovulatory period. In Fertilization of the Human Egg in Vitro, pp. 35-55. Eds. H. M. Beier \& H. R. Lindner. Springer, Berlin.

Thibault, C.G. (1972) Final stages of mammalian oocyte maturation. In Oogenesis, pp. 397-411. Eds J. D. Biggers \& A. W. Schuetz. University Park Press, Baltimore. 